\title{
CINEMA DE BOCA EM BOCA \\ ESCRITOS SOBRE CINEMA
}

Rodrigo Cazes Costa é doutorando em estudos de literatura na PUC-Rio.

E-mail: rcazesc@ccard.com.br

\section{RESUMO}

Esta resenha pretende discutir a importância do lançamento do livro Críticas de Inácio Araújocinema de boca em boca, ocorrido em 2010.

\begin{abstract}
This review discusses the importance of the book Cinema de boca em boca-escritos sobre cinema, published in 2010.
\end{abstract}

A questão da crítica, tanto em seu aspecto teórico como em sua atividade prática, é um tema fundamental para aqueles que se dedicam ao estudo dos objetos artísticos. Primeiramente, deve-se definir o que se entende por crítica de arte. Ezra Pound, em seu texto seminal sobre a questão no que diz respeito à arte literária (2003) traça um caminho básico para a função primordial do crítico ${ }^{i}$ : escolher os objetos que são dignos de apreciação, separando o joio do trigo e efetuando revisões no panorama histórico. A partir deste paradigma, a crítica deve operar. No entanto, a crítica, entendida como atividade de avaliação e julgamento de objetos artísticos, não é uma atividade predominante dentro da academia. $\mathrm{Na}$ academia os objetos são examinados a partir de uma reflexão lenta, embasada por outras reflexões anteriores e não através de um contato pioneiro que tem por objetivo avaliar as qualidades e defeitos de um objeto que ainda não foi devidamente estudado que não possui uma teoria por trás de si. O mais próximo a que a academia costuma se aproximar da crítica é o ensaio (ADORNO, 1994). A crítica exige uma velocidade na tomada de posições que não é própria da academia. A crítica acaba, então, por encontrar o seu terreno de excelência para manifestação nos veículos jornalísticos. Jornais, $b \log s$, revistas, são os locais onde o crítico poderá examinar os objetos artísticos, elegendo aqueles que ele acha merecerem maior atenção de seu público leitor e aqueles que não.

Muitas vezes o espaço de que o crítico dispõe em seu veículo de comunicação é bastante reduzido, bem menor do que o desta resenha, por exemplo. Dispondo de um espaço reduzido para sua argumentação, o crítico deverá possuir o talento de realizá-la em uma perspectiva semelhante à do pensamento por aforismos, defendido por Nietzsche (2001). Sob tais perspectivas é exemplar a trajetória de Inácio Araújo para a crítica cinematográfica brasileira. Há quase trinta anos crítico da Folha de São Paulo, Inácio é um exemplo para aqueles que apreciam a capacidade de separar o joio do trigo na produção cinematográfica brasileira e mundial e, principalmente, a qualidade de, num espaço bastante reduzido de texto, argumentar com precisão e afetividade pela 
matéria de que trata. Deste modo, é salutar o lançamento, pela Editora Imprensa Oficial, de São Paulo, de uma seleção de suas críticas publicadas nos últimos vinte e oito anos na Folha de São Paulo, organizadas em ordem cronológica pelo jornalista Juliano Tosi. As críticas passeiam por filmes de diversos gêneros e estilos: os clássicos de Hollywood, as produções da Nouvelle Vague francesa, os cinemas modernos ${ }^{\mathrm{ii}} \mathrm{em}$ geral, o cinema brasileiro de todas as espécies. Os textos de Inácio Araújo servem como primeira lição contra e para aqueles que separam o cinema por gêneros ou estilos, como se esses fossem um certificado de qualidade prévia. Bom gosto contra mau gosto.

Exemplo da capacidade de Inácio de olhar para os gêneros tidos como menores do cinema é a crítica, publicada em 8 de janeiro de 1984, de um clássico da ficçãocientífica, realizado pelo mestre norte-americano dos filmes $\mathrm{B}$, Roger Corman, $O$ homem dos olhos de raios-x (The man with the $x$-ray eyes (EUA, 1963). Habitualmente relegado pelos críticos de bom gosto a uma categoria menor, o filme recebe a devida recompensa na crítica de Inácio:

Eles me impressionam menos do que a envergadura trágica que Corman confere a seu tema, a partir da identidade entre conhecimento e solidão. Para tanto, não é necessário que se afaste de umas tantas convenções da série $B$, como a caracterização típica dos cientistas ou mesmo a pobreza dos meios. Como em quase toda história de baixo orçamento, a que faltam tempo de rodagem e recursos, até para elenco de apoio, a solidão é também um dado invariável (...) (TOSI, 2010, p.65).

O diálogo com os gêneros menores não é, com certeza, uma atuação pioneira de Inácio, os críticos da Cahiers du Cinéma já efetuavam tal operação, mas, no Brasil, em meados dos anos 1980, defender um filme "popularesco" em um jornal voltado para as classes econômicas mais abastadas da população e os setores intelectualizados da mesma não deixava de ser um ato corajoso, mesmo numa década onde alguns paradigmas culturais estabelecidos pelo projeto da modernidade e pelo projeto cultural modernista estivessem sendo quebrados. Até hoje os intelectuais que admiram Glauber Rocha como artista e pensador muitas vezes esquecem que ele defendia o cinema de José Mojica Marins nos anos 1960, como atitude política e estética.

Mas Inácio Araújo não se sente à vontade apenas sendo iconoclasta. Ele também passeia com desenvoltura pelo cinema consagrado pelos críticos e acadêmicos, assim como aquele consagrado pelo bom gosto do establishment, das premiações, como o Oscar. Em sua crítica de Ninotchka (Ninotchka, 193, Ernst Lubitsch), Inácio destaca alguns pontos singulares do filme:

Em Ninotchka, Lubitsch introduziu as ambigüidades do amor num gênero pouco elástico- a sátira política- fazendo do partido o terceiro lado do triângulo. Com isso, conferiu ao filme uma capacidade de respiração rara, em que Garbo não só renuncia aos espartanos ideais bolcheviques como permite que seu tipo ideal de mulher se torne, temporariamente, tangível. (TOSI, 2010, p.121).

A capacidade de trânsito entre variadas escolas do cinema serve para oxigenar o processo de pensamento crítico, que não fica aferrado a questões regidas por um projeto 
de crítica jornalística que está preso a uma má leitura da modernidade e mesmo do modernismo, enxergando no cinema um primo pobre da literatura, o qual só tem valor artístico quando engajado em temas nobres, literatos ou formas modernistas. Mas Inácio também trata deste tipo de "cinema de arte", colocado, em termos de importância de projeto, em pé de igualdade com um cinema narrativo clássico hollywoodiano realizado com grandes recursos financeiros e humanos (BORDWELL, 2005) e o mesmo estilo narrativo realizado sem esses recursos. Na crítica escrita para Memórias do cárcere (Nelson Pereira dos Santos, Brasil, 1984) Inácio busca articular variadas formas de se ver e fazer cinema em um filme que simboliza uma união do cinema brasileiro moderno (XAVIER, 2001) e de um cinema brasileiro que busca um grande público, busca a comunicação, a partir das memórias de um dos mais consagrados escritores brasileiros, Graciliano Ramos:

É o filme de um mestre em pleno domínio de seus meios, capaz de levar o afeto do espectador, jogar com seus sentimentos, tirar-lhe o fôlego, levar-lhe às lágrimas. Mas é, sobretudo, um filme sobre a escrita e a prisão (...)

Por outro lado, é um filme sobre cinema. Ali onde o escritor anota, rabisca, lembra, o cineasta decupa (...) (TOSI, 2010, p.81).

$\mathrm{Na}$ ligação entre o cinema (popular) e a literatura (elite) está a chave para a compreensão do pensamento crítico de Inácio Araújo, disposto a suplantar tal dicotomia, infelizmente ainda presente no jornalismo e mesmo na academia. 


\begin{abstract}
' A teoria de Pound sobre a arte traz um problema: nela, há uma grande separação entre a arte e o meio social que a cerca. Mesmo sem crer em tal separação, acredito que a reflexão de Pound sobre a crítica, em sua premissa básica, de separação do joio e do trigo, é válida. Um desdobramento de tal questão em relação à literatura brasileira pode ser vista no debate entre Antonio Candido e Haroldo de Campos a respeito do papel do barroco na historiografia da literatura brasileira.

ii De acordo com a definição de André Bazin (1991) cinema moderno é aquele que, a partir da influência de Orson Welles e do neorrealismo italiano privilegia a profundidade de campo e os planos longos.
\end{abstract}

\title{
Referências bibliográficas
}

ADORNO, Theodor W: "O ensaio como forma", in: Theodor W Adorno. Gabriel Cohn (ed.). São Paulo: Ática, 1994,

NIETZSCHE, F. A Gaia Ciência. São Paulo: Companhia das Letras, 2001.

POUND, Ezra. ABC da literatura. São Paulo: Editora Pensamento-Cultrix, 2003.

TOSI, Juliano. Críticas de Inácio Araújo- Cinema de Boca em Boca. São Paulo: Imprensa Oficial, 2010.

BORDWELL, David. "O cinema clássico hollywoodiano: normas e princípios narrativos". in: RAMOS, Fernão(org.).Teoria contemporânea do cinema Vol.II. São Paulo: Senac, 2005.

XAVIER, Ismail. Cinema brasileiro moderno. São Paulo: Paz \& Terra, 2001.

BAZIN, André. Cinema-Ensaios. São Paulo, Brasiliense, 2001. 